\title{
Sinus histiocytosis with massive lymphadenopathy
}

\author{
David K Stones, Charmaine Havenga
}

\begin{abstract}
Sinus histiocytosis with massive lymphadenopathy is a well recognised, but rare cause of lymphadenopathy in the first decade of life. Three cases presenting with nodal disease are described. The eyelids were involved in one case. The clinical, laboratory, and biopsy findings are discussed and compared with previously .reported cases.
\end{abstract}

Sinus histiocytosis with massive lymphadenopathy (SHML) is a rare cause of lymphadenopathy in children and was first described by Rosai and Dorfman in 1969. 'The patients usually present with cervical lymphadenopathy. Multiple other lymph node groups can be involved and the extranodal manifestations of the disease are well documented. It is a disease of unknown aetiology, although some, but not all, cases have been linked to Epstein-Barr virus infection. The Epstein-Barr virus may alter the immune reaction to a specific, but unknown, antigen.

The clinical features are determined by the lymphadenopathy. The signs and symptoms depend on the size, site, and number of the lymph nodes involved. The site and appearance of extranodal disease may also be characteristic.

The laboratory findings are variable and there are no pathognomonic biochemical abnormalities. The histological features are specific but the diagnosis may be easily confused with sinus hyperplasia. ${ }^{1}$ The latter may be due to non-specific infections or infections such as cytomegalovirus, Epstein-Barr virus, rubella, mycobacterium tuberculosis, and brucella.

The prognosis is good with a mortality rate of $7 \%{ }^{2}$ and a spontaneous remission rate of $20 \%$. There is no specific treatment for the enlarged lymph nodes.

\section{Case report}

The clinical features and laboratory investigations of the three patients are summarised in the table.

The patients were under 10 years of age and black. The history before presentation varied from three weeks to two years. The prominent feature in all three cases was appreciable cervical lymphadenopathy. In one patient the cervical nodes were smaller but there was prominent swelling of both lower eyelids and temporalis muscles. This patient also was physically and mentally retarded.

All had a raised erythrocyte sedimentation rate and platelet count. None was anaemic and two patients had a neutrophil leucocytosis. The total protein and the gammaglobulin in all three patients was increased and the raised gammaglobulin was of the IgG and IgM class.

No lymphadenopathy was evident either on radiographs of the chest or computed tomography of the mediastinum. The tuberculin skin testing was negative in all three patients.

Lymph node biopsy was performed under general anaesthesia. In all three this showed the
Department of Paediatrics and Child Health

Haematology/Oncology,

University of the

Orange Free State,

Bloemfontein,

South Africa

David K Stones

Charmaine Havenga

Correspondence and reprint

request to: $\mathrm{K}$ Stones, Department of Paediatrics

Department of Paed

Haematology/Oncology, University of

Orange Free State,

Orange Free State,

Pelonomi Hospital,

PO Box 339 (G69),

Bloemfontein,

Republic of

South Africa 9300

Accepted 18 December 1991
Clinical and laboratory results in patients with SHML

\begin{tabular}{|c|c|c|c|}
\hline & \multicolumn{3}{|l|}{ Patient } \\
\hline & 1 & 2 & 3 \\
\hline $\begin{array}{l}\text { Age (years) } \\
\text { Sex } \\
\text { Duration of symptoms } \\
\text { Fever } \\
\left(>37 \cdot 5^{\circ} \mathrm{C}\right)\end{array}$ & $\begin{array}{l}1 \cdot 3 \\
M \\
3 \text { weeks } \\
\text { Yes }\end{array}$ & $\begin{array}{l}5 \cdot 3 \\
\text { F } \\
4 \text { months } \\
\text { No }\end{array}$ & $\begin{array}{l}8 \cdot 9 \\
M \\
2 \text { years } \\
\text { Yes }\end{array}$ \\
\hline $\begin{array}{l}\text { Clinical: } \\
\text { Lymph nodes: }\end{array}$ & $\begin{array}{l}\text { Submandibular, bilateral, } \\
15 \times 15 \mathrm{~cm} \text {, hard, } \\
\text { mobile, non-tender }\end{array}$ & $\begin{array}{l}\text { Submandibular, bilateral, } \\
7 \times 7 \mathrm{~cm} \text {, hard, } \\
\text { mobile, non-tender }\end{array}$ & $\begin{array}{l}\text { Submental, bilateral, } \\
1 \times 1 \mathrm{~cm} \text {, hard, } \\
\text { mobile, non-tender }\end{array}$ \\
\hline $\begin{array}{l}\text { White cell count }\left(\times 10^{9} / 1\right) \\
{[3 \cdot 6-9 \cdot 6]}\end{array}$ & $15 \cdot 9$ & & \\
\hline $\begin{array}{l}\text { Neutrophils }\left(\times 10^{9} / 1\right) \\
\text { Platelets }\left(\times 10^{9} / 1\right) \\
{[140-440]}\end{array}$ & $\begin{array}{l}12 \cdot 3 \\
596\end{array}$ & $\begin{array}{l}10 \cdot 1 \\
551\end{array}$ & $\begin{array}{l}6 \cdot 0 \\
488\end{array}$ \\
\hline $\begin{array}{l}\text { Erythrocyte sedimentation rate (mm/hour) } \\
\text { Lymphocytes (ratio TH:TS) } \\
{[>1 \cdot 1]}\end{array}$ & $\begin{array}{l}58 \\
1 \cdot 9\end{array}$ & 30 & $\begin{array}{l}70 \\
0 \cdot 8\end{array}$ \\
\hline$\underset{[2-28]}{\text { Globulin }(g / 1)}$ & 40 & 33 & 43 \\
\hline$\underset{[38-52]}{\operatorname{Albumin}}(\mathrm{g} / \mathrm{l})$ & 37 & 36 & 36 \\
\hline $\operatorname{IgG}(g / 1)$ & 24 & 16 & 28 \\
\hline $\begin{array}{r}\operatorname{IgM}(\mathrm{g} / \mathrm{l}) \\
{[0 \cdot 5-2]}\end{array}$ & $4 \cdot 2$ & $2 \cdot 1$ & $5 \cdot 2$ \\
\hline
\end{tabular}

Normal results are shown in square brackets. 
classical histological features of SHML. In the patient with eyelid involvement the histological changes in the lymph node were only recognised when in addition the eyelid was biopsied. In this biopsy specimen the histiocytes showed a tendency to aggregate in solid sheets. Phagocytosis of lymphocytes with connective tissue containing prominent lymphocytes and macrophages was also seen.

One child has been lost to follow up. In the two patients who have been followed up for one year the lymph nodes have decreased in size without treatment. The child with the extra nodal involvement has also shown some resolution of his disease.

\section{Discussion}

There are to date more than 400 cases of sinus histiocytosis with massive lymphadenopathy registered in the registry at Yale University. ${ }^{1}$ Cases have been described from all continents. The three patients with the SHML described in this report show many of the clinical features as described in the literature. ${ }^{1-4}$

The ages ranged from $1 \cdot 3$ years to almost 9 years of age. This is the typical age range of the disease as described previously. ${ }^{2-5}$ Most present in the first decade of life and almost $80 \%$ by the age of 20 years. ${ }^{3}$ The youngest case presented at birth. A male predominance has been described in the literature ${ }^{1}$ with male to female of ratio of $2: 1 .^{3}$

The clinical features of the three patients reported are similar to the classical description of SHML. There was massive bilateral cervical lymphadenopathy in two patients, while in the third the lymph nodes were much smaller but the extranodal manifestations were more prominent. The cervical lymph nodes are involved in up to $97 \%$ of patients. ${ }^{2-4}$ Other lymph node groups can be involved and this includes axillary, inguinal, abdominal, and mediastinal groups. The involvement is usually bilateral and painless but has been described as tender in some patients. ${ }^{1}$ Extranodal disease occurs in $30 \%$ of patients ${ }^{136}$ and can involve many organ systems. Sneige and Batsakis state that the nasopharynx is the most common extranodal site of the disease followed by the salivary tissue and oral cavity. ${ }^{2}$ Foucar, Rosai, and Dorfman in a review of the literature state that skin involvement is at least as common as nasal cavity and paranasal sinus involvement. ${ }^{1}$ One patient in this report had lower eyelid involvement, a well described entity in SHML. ${ }^{457}$ This is the fourth most common site of extranodal disease. ${ }^{1}$

Fever is a prominent feature in some cases and two of our cases were feverish. No definite cause could be found for the mental retardation and short stature in one patient. Short stature has been described occasionally in SHML.1

The results of laboratory investigations have been described in detail in the literature. ${ }^{1-5}$ The three patients reported had a raised erythrocyte sedimentation rate, two had a neutrophil leucocytosis, and the third had a normal white cell count. Anaemia is mentioned in some case reports $^{135}$ but was not present in any of our patients. Other haematological abnormalities include haemolytic anaemia and hypochromic microcytic anaemia. ${ }^{1}$ The three patients reported had an increased platelet count, an abnormality not previously documented in the literature.

Immunological abnormalities have been described $^{127}$ and a reversal of the TH:TS (T lymphocyte helper to suppressor) cell ratio was noted. Only one of our patients had an abnormal TH:TS ratio. None of three patients had a history of abnormal infections as described by Sneige and Batsakis. ${ }^{2}$

Abnormalities in the serum proteins have also been described. ${ }^{1}$ The albumin is often low and other serum proteins may also be abnormal. In the three cases reported the albumin was marginally reduced and the immunoglobulin IgG and IgM concentrations were significantly raised.

The histological features of SHML have been described in detail previously. ${ }^{1-5}$ There are classical histological features regardless of the nodal or extranodal sites. The most prominent cells are histiocytes, which show appreciable phagocytosis. This phagocytosis is more prominent in the lymph nodes and involves lymphocytes, plasma cells, and other cellular debris. Other cell lines that are seen include lymphocytes and plasma cells. In the lymph node there is dilatation of the sinuses that is filled with the histocytes, and in the extranodal sites they arrange themselves into cords or nests to create the illusion of sinuses. ${ }^{1-5}$ Fibrosis is often more prominent in the extranodal sites. The histology of the cases reported here showed the above features. The differential diagnosis on histological examination includes the following disease entities: metastatic melanoma, Hodgkin's disease, a variety of infectious diseases, and Langerhans' histiocytosis. In practice the most common problem is to distinguish SHML from focal nodal sinus hyperplasia that results from a wide variety of agents. ${ }^{1}$

In most cases treatment is not necessary as SHML is usually not life threatening or damaging to organ function. There is no specific treatment for the disease and some cases have been treated with systemic immunosuppression, ${ }^{489}$ local excision, ${ }^{49}$ and even with radiotherapy. ${ }^{48}$ These treatments have been reserved for those cases with life threatening complications related to either the patency of the airways ${ }^{9}$ or central nervous system dysfunction. ${ }^{4}$ In some cases patients have requested surgery because of the massive disfiguring lymphadenopathy. ${ }^{8}$ Many chemotherapeutic drugs have been used, ${ }^{2}$ both alone and in combination. It appears that use in combination has the best results, although the remission figures do not approach those seen with malignant haematological disease. Radiotherapy also gives poor results. ${ }^{8}$

In conclusion this series of three patients conforms to the typical features of SHML as described in the literature. Although it is an uncommon cause of lymphadenopathy the implications are important for the patient, particularly with regard to the prognosis and management. An abnormal feature in all of the three patients reported that has not been 
described previously is a raised platelet count or thrombocytosis.

The authors wish to thank GJ Viviers, chief medical superintendent of Pelonomi Hospital, for permission to publish.

1 Foucar E, Rosai J, Dorfman R. Sinus histiocytosis with massive lymphadenopathy. (Rosai-Dorfman disease) review of the entity. Semin Diagn Pathol 1990;7:19-73.

2 Sneige N, Batsakis J. Sinus histiocytosis with massive lymphadenopathy. Ann Otol Rhinol Laryngol 1989;98: 241-2.

3 Sanchez R, Rosai J, Dorfman R. Sinus histiocytosis with massive lymphadenopathy: an analysis of 113 cases with special emphasis on its extranodal manifestations. Lab Invest 1977;36:349-50.
4 Stopack S, Dreizen N, Zimmerman E, O’Neill F. Sinus histiocytosis presenting as epibulbar mass. Arch Ophthalmol 1988;106:1426-8.

5 Karcioglu Z, Allam B, Insler M. Ocular involvement in sinus histiocytosis with massive lymphadenopathy. $\mathrm{Br} \mathcal{F}$ Ophthalmol 1988;72:793-5.

6 Wong H, Wright J, Harry J. Rosai-Dorfman disease (sinus histiocytosis with massive lymphadenopathy) with cutaneous and ocular involvement: a case report. Eye cutaneous and

7 Salmon J, Duffield M. Sinus histiocytosis with massive lymphadenopathy. Am $\mathcal{f}$ Ophthalmol 1989;107:549-50.

$8 \mathrm{Komp} \mathrm{MD}$. The treatment of sinus histiocytosis with massive lymphadenopathy (Rosai-Dorfman disease). Semin Diagn Pathol 1990;7:83-6.

9 Suarez C, Rust G, Zeller P, Messmore H, Silberman S. Sinus histiocytosis with massive lymphadenopathy: remission with chemotherapy. Am 7 Pediatr Haematol Oncol 1983;5: 235-41.

\section{Proselytising neurodevelopmentalists}

Here's a philosophical question for you. Can open mindedness and evangelism coexist? The question came to mind when I received through the post a copy of a magazine called Early Age which is to be published quarterly by a firm of marketing consultants in Halifax. The purpose of the publication is to promote the work of Dr Ferenc Katona and his team at the Budapest department of developmental neurology and rehabilitation (how many evangelical neurodevelopmental departments can a single city produce?). The author, or authors, of the articles is not stated but we are told from the start that 'on paper at least', the department is 'gaining an international reputation as a leading centre of excellence in the precise diagnosis of abnormal brain development at a very early age'. An intriguing phrase that, 'on paper at least'. Presumably it means that people write about the excellence but never talk about it. Undercover writing I suppose. Strange. A few pages later the virtues of open mindedness and eclecticism are extolled. Other schools make the mistake of stressing 'the singular importance of their own method'. Dr Katona's school, of course, would never do such a thing. Modesty would forbid it. But if you would like to attend a seminar in London, go on a six day course in Budapest, or subscribe to the newsletter, they will be prepared to share their internationally reputed (on paper) excellence with you. But only if you want to. Is my temporal lobe misbehaving or do you get that déjà $v u$ feeling too? 